\title{
The Effects of Inflation (1960-68)
}

\author{
by ALBERT E. BURGER
}

HE MAJOR GOALS of economic stabilization policy are a full-employment level of real output and a stable price level. Over the first five years of the current economic expansion which began in early 1961, the goal of full employment dominated discussions of policy. In January 1966 the interim target goal of 4 per cent unemployment was reached. Since early 1966 most studies of unemployment have been concerned with unemployment by specific classes or groups rather than total unemployment. At an aggregate level, the problems of achieving a stable price level have increasingly dominated the attention of the policymakers and the public.

The objective of a full-employment level of real output is a desirable goal of economic stabilization policy. If the economy is operating at less than its potential level of real output there is waste, not only from the standpoint of individuals who are un. employed, but from an aggregate viewpoint. There is less real output being produced than the economy could produce, given its endowment of factors of production, the degree of skill and training of the labor force, and the available technology. By moving from a position of underemployment to one of maximum utilization of resources, a larger flow of real goods may be made available for all members of the economy.

Most people can see the inherent dangers of socalled hyperinflation. Germany in the post-World War I period, when prices rose by a faotor of 100 billion in one year, the Eastern European countries of Poland and Hungary in the 1921-23 period, and China in the post World War II period, stand out as very clear examples of the severe political as well as economic consequences of hyperinflation.

However, to the individual, effects of inflation are less immediately clear when the rate of change of prices increases from 1.3 per cent to 5 per cent over a period of four years, as was experienced in the United States during 1964-68. Indeed, sometimes there is even confusion as to just what the term inflation means. A careful distinction must be made between changes in relative prices of assets and changes in the same direction of prices of all assets except money. ${ }^{1}$ Changes in relative prices play an important role in a dynamic growing economy. In a market-directed economy such as ours, changes in relative prices of goods and services and classes of factors of production are the mechanism by which resources are directed to produce the real goods and services that maximize the satisfaction of individuals in the economy.

Individuals purchase real goods and services because the consumption of these iterns yields satisfaction (or as economists would say, utility) to the individual purchaser. Exactly defined, inflation refers to a situation where an individual can no longer purchase as large an amount of utility for a given money outlay. Because a satisfactory means has not been developed to quantify the utility that individuals receive from consuming goods and services, a less exact definition of infation must be used.

The term inflation is applied operationally to a situation where the exchange value of the medium of exchange (money), in terms of real goods and services, is decreasing. We attempt to measure whether the general level of prices has increased, or whether there has only been a change in relative prices, by the use of a price index. Changes in the price index reflect changes in the total cost of a representative market basket of goods. For example, if a price index rises from 100 to 105 over a period of time, we say that the exchange value of money in terms of this representative market basket of goods is 4.8 per cent less.

The purpose of this article is to examine the effects of inflation on individuals in their separate roles as income earners and holders of financial and real as-

\footnotetext{
1An individual's holdings of assets, the current dollar value of which measures his nonhuman wealth, may be divided into two broad classes - real assets and financial assets. Real assets are items which yield a direct flow of consumption or production services to the asset holder. Financial assets are items that represent a claim on real assets or other financial assets.
} 
sets. The analysis is limited to the eight-year period 1960 through 1968. No attempt is made to diseuss long-run trends. For comparison purposes, the period from $1960-68$ is divided into two four-year periods: 1960-64 when overall prices remained relatively stable, and 1964-68 when the rate of increase of prices accelerated.

The analysis is limited to the effects of inflation on individuals in their separate roles on the average. Any one individual is not exclusively an income earner, not just a homeowner, nor just a holder of financial assets. Quite likely, he is all three. We can judge whether a particular individual "benefited" or "lost" in a given period of time only by examining his total balance sheet. During the latter comparision period some individuals experienced greater increases in real income flows and in the real value of the stock of assets they held than during the 1960-64 period. Others fared worse with respect to these items than during the earlier comparison period. ${ }^{3}$

\section{An Overall Look at the Period 1960 Through 1968}

At the aggregate level, both of the comparison periods show remarkable economic expansion. Over the first four-year period, real GNP increased by $\$ 93.4$ billion, a 19 per cent increase. During the next four years, real GNP grew by an additional $\$ 126.5$ billion, up 22 percent. ${ }^{3}$ Per capita real GNP also rose markedly, by 12 per cent from 1960 through 1964, and then by 16 per cent from 1964-68.

The two periods were dissimilar in at least two important aspects: prices and unemployment. The first period, I960 through 1964, was characterized by a period of prevailing price stability: the consumer price index rose at an average rate of 1.2 per cent, wholesale prices showed almost no change, and the broader index, the GNP deflator, rose at an average annual rate of only 1.3 per cent. The second fouryear period was characterized by an accelerating price level. From an increase of only 1.3 per cent in 1964, the consumer price index increased at an average rate of 1.7 per cent in 1965 , increased to a 2.9 per cent rate for 1966 , slowed in the mini-recession of the

2Since the household sector is a net monetary creditor (its monetary assets exceed its monetary liabilities), this sector loses real wealth in periods of inflation to net debtor sectors such as the government sector and business sector.

The 22 per cent increase in real GNP in the latter four years is an even more remarkable rise when one considers that this increase was achieved starting in 1965 from a much higher level of resource utilization than prevaled in $1960 * 61$.

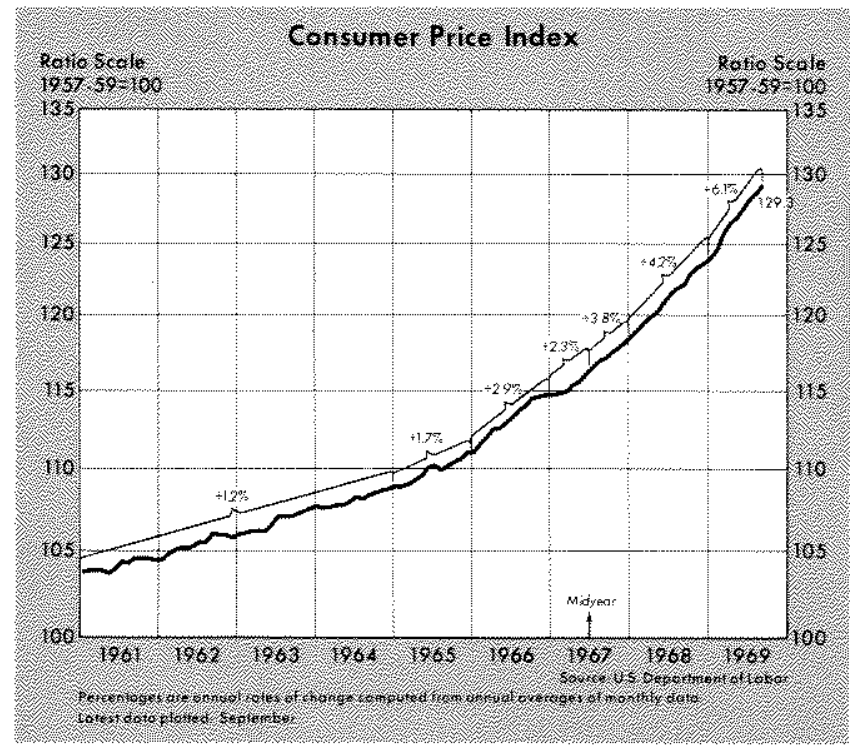

first part of 1967, and then again began its upward movement. Over the last half of 1967 , the consumer price index rose at a 3.8 per cent annual rate and then accelerated to a 4.7 per cent rate for 1968 .

The first of our four-year periods was characterized by anemployment above 5 per cent. In 1962 the unemployment rate was 5.5 per cent, a sharp drop from 6.7 per cent in the previous year. Over the next three years the unemployment rate remained at ap. proximately the 1962 level. The second period, 1964 through 1968, is characterized by another sharp break in the per cent of the labor force unemployed. In 1965 the unemployment rate fell to 4.5 per cent and in 1966 reached an average of 3.8 per cent, a low level believed almost unattainable in a growing economy in the early 1960's.

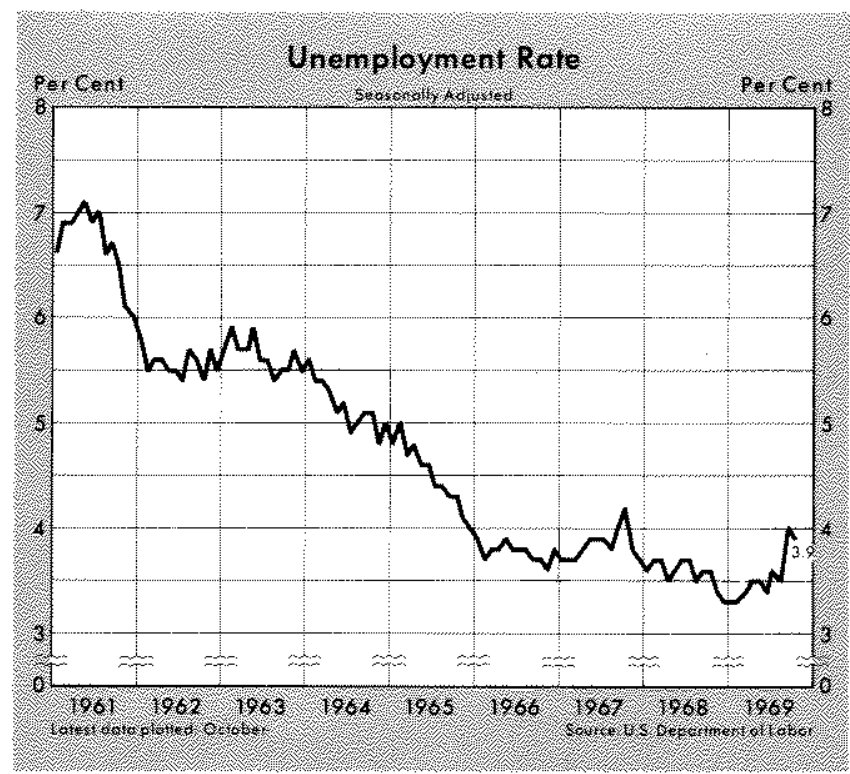


Let us now turn to the consideration of each of several different groups and sce how, on the average, each of these groups actually fared in our two comparison periods.

\section{How Do We Judge Whether Individuals Have Benefited or Lost?}

If over a period of time an individual's ability to command real output increases, we say he has "benefited." If over a period of time an individual's ability to command goods and services decreases, we will say he has "lost."

\section{Real versus Nominal Benefits and Losses}

An individual's ability to command goods and services depends upon his ability to command money balances. Over time, however, the exchange ratio between a given amount of goods and services and a given amount of money balances may change. A change in the amount of money balances a person can command is referred to as a change in his nominal command over goods and services. A change in the amount of goods and services a given amount of money balances commands is called a change in the individual's real command over goods and services. A careful distinction must be made between nominal and real gains and losses. For example, if a person's holdings of money balances rises from $\$ 100$ to $\$ 200$, his nominal gain is a doubling of his money balances. If, however, over the same period of time, prices of all goods and services double, then his real gain is zero. The confusion of nominal gains with real gains is called a "money illusion" by economists. Economists attempt to strip away the vel of money by adjusting nominal changes with a price index.

\section{Two Measures}

Two closely related measures of an individual's command over real output are used to decide whether he has benefited or lost during a period of time. The first measure is income, which is defined as the flow of money payments an individual receives over a period of time. A person's income is one major determinant of the amount of goods and services he can command over time.

The second measure used is net wealth. An economic unit's net wealth is defined as: Net Wealth = Assets - Liabilities. ${ }^{4}$

\The difference between assets and liabilities may also be represented by the terms net worth or equity.
Assets and liabilities are divided into two major classes - real and monetary. Monetary assets refer to assets exchangeable only for a fixed amount of dollars. Real liabilities are obligations to deliver a real asset whose exchange value in terms of money may vary. The individual's balanee sheet appears as:

\begin{tabular}{ll}
\multicolumn{1}{c}{ Assets } & \multicolumn{1}{c}{$\frac{\text { Liabilities }}{\text { Monetary Liabilities }}$} \\
Real Assets & Real Liabilities \\
& Net Wealth
\end{tabular}

If the dollar value of the items on the left-hand side of the ledger equals the dollar value of the items, excluding net wealth, on the rightwhand side of the ledger, then net wealth equals zero. To the extent that the dollar value of assets exceeds the dollar value of liabilities, the net wealth of the economic mit is greater than zero.

If the net wealth of an economic unit expressed in current dollars rises between two periods in time, then the economic unit's available command over money balances has risen. However, we would say the economic unit benefited only if this greater potential command over money balances represents command over a larger set of real goods and services.

\section{Income Flows}

Most individuals, when looking back over two periods of time and attempting to judge whether they fared better in the first period or in the second period, consider not only changes in their holdings of assets, but also consider how their flow of nominal income changed. To many individuals this last consideration is the more important of the two.

When asked in which of two periods he benefited more, an individual's answer will probably depend upon the answers to these two questions:

(1) In which period did his income increase the most?

(2) In which period did changes in his income allow him to command the greatest increase in flows of real goods and services?

Although questions (1) and (2) are related, they are not identical. Referring to the discussion of nominal versus real changes we note that the period which shows the greatest increase in nominal terms is not always necessarily the same period that reflects the greatest increase in real terms.

In the 1960 through 1964 period, employment of production and non-supervisory workers in nonag- 


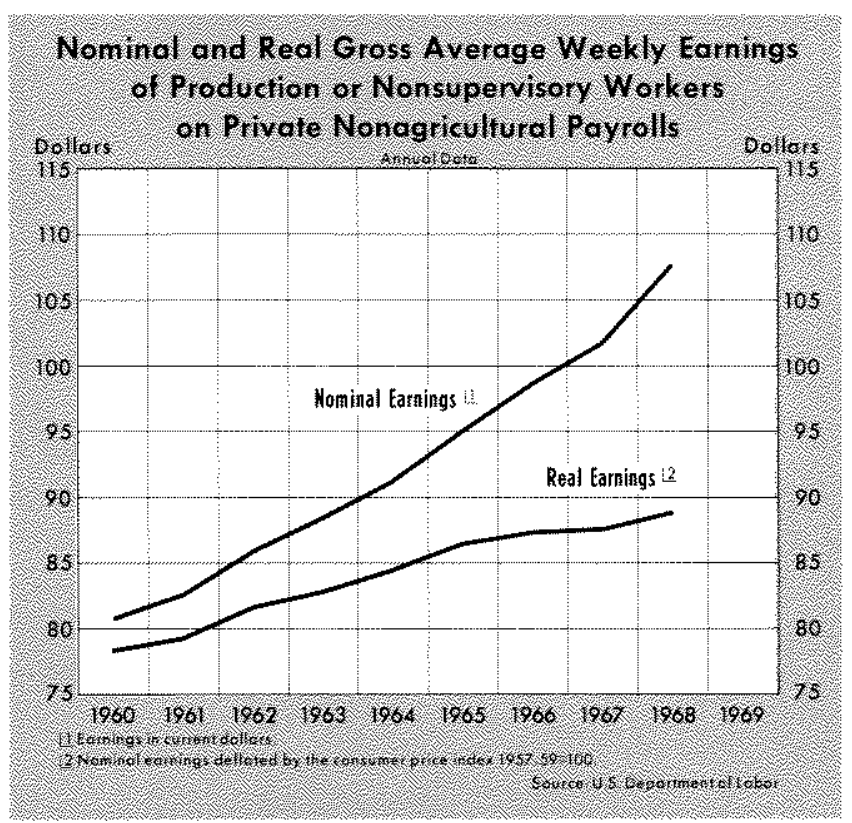

ricultural establishments expanded by 5.4 per cent, and gross average weekly eamings rose by 13.2 per cent in nominal terms and 8 per cent in real terms. Over the next four years employment in this area accelerated, increasing by 14.2 per cent. Average weekly earnings grew by 18 per cent. However, considering the rapid rise of prices, the real gain in purchasing power was about 5.2 per cent, only about two-thirds as great as that experienced during the previous four years of general price stability.
To gain some insight into the relative income performance of different categories of workers, let us examine selected working groups as presented in data of the Bureau of Labor Statistics.

\section{Skilled Compared to Unskilled Workers}

As illustrated in Table I, both skilled and unskilled workers experienced a more rapid rise in nominal wages in the most recent period than in the previous four-year period. However, changes in real wages show quite a different picture. Since 1964 , as the rate of increase of prices rose year after year, the percentage increase in real wages of both skilled and unskilled workers was only about one-half as large as in the 1960-64 period of relatively stable prices. Neither skilled nor unskilled workers benefited more in inflation than in the comparison period of price stability.

Comparatively, unskilled workers benefited least from the recent period of inflation. In 1964 their flow of real wages permitted them to command 8.7 per cent more real goods and services than in 1960. In 1968, after four years of inflation, real wages of unskilled workers had risen only 4.1 per cent.

\section{Union Workers}

Table II presents average hourly wage rates for classes of union workers in selected trades. Table III shows the percentage changes in nominal and real

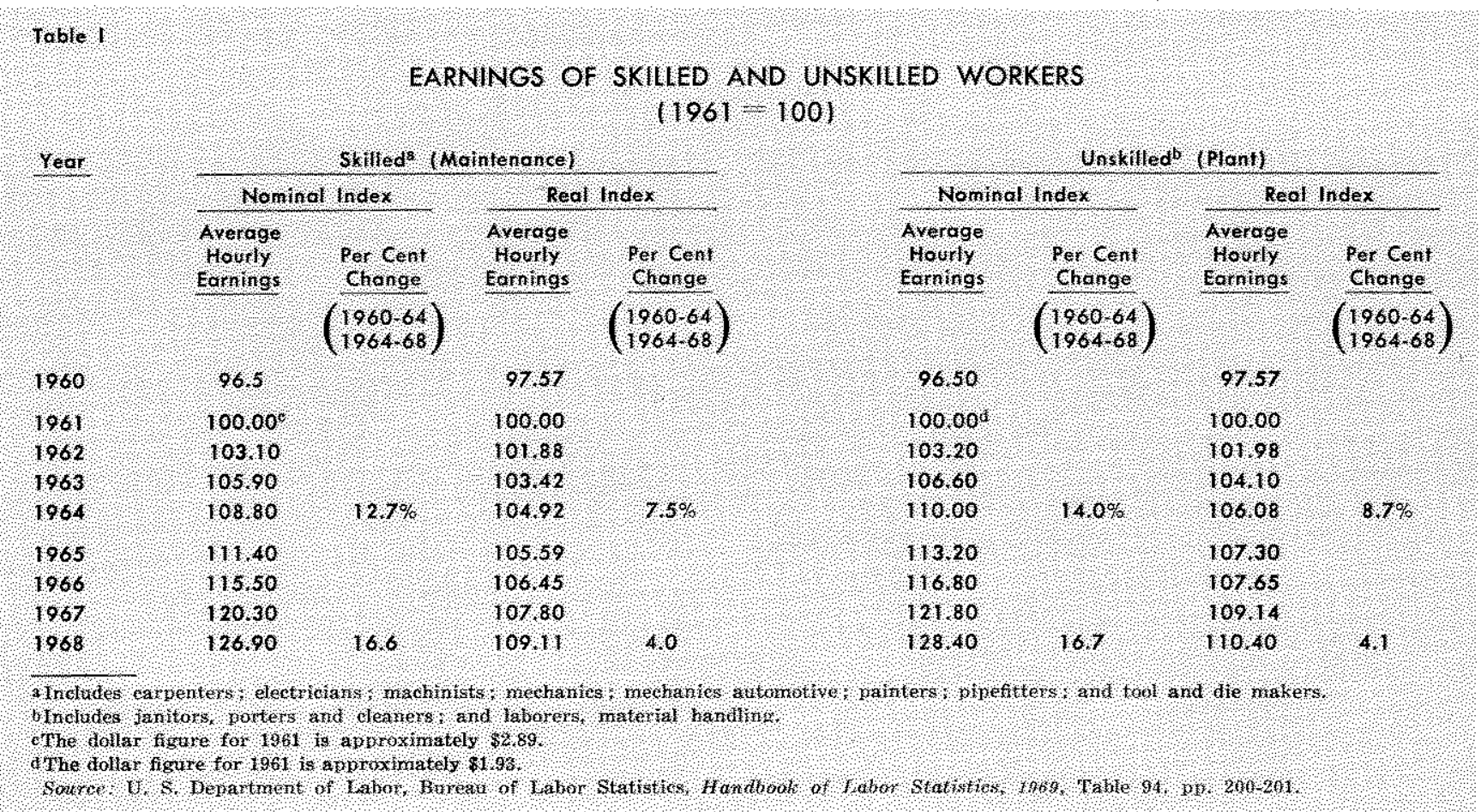




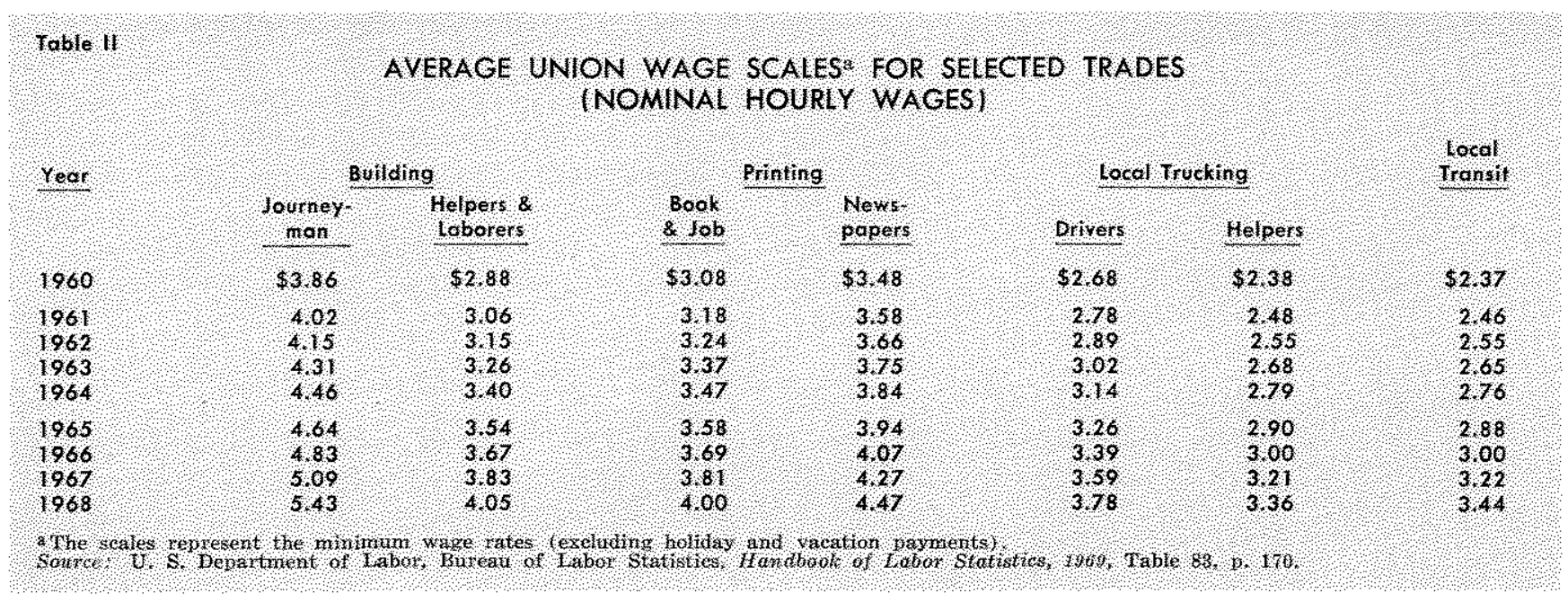

wages for each of these classes of union workers in the two four-year comparison periods. These tables illustrate that many of the union groups covered experienced more substantial percentage increases in nominal wages over the 1964-68 period than during the 1960-64 period.

However, looking at changes in real wages in Table III, it appears that most union groups received smaller percentage increases in real wages in the recent period of rapidly rising prices than in the 1960-64 period. The increases in the payments received for productive services by union workers in local trucking, building, and printing trades in the 1964-68 period represented substantially smaller percentage increases in their command over real goods and services than what they experienced in the previous fouryear period. Only local transit workers, of the groups considered, received the same percentage rise in real wages in both periods.

\section{White Collar Workers}

Table IV shows that a broad class of workers in white collar jobs experienced a more rapid rise in nominal wages in the latter period than in the 1960-64 period. Nevertheless, as was the case with most of the union groups surveyed, white collar workers received a substantially smaller percentage increase in real wages in the more recent four-year period. In the 1964-68 period real wages of white collar workers included in Table IV rose only 3.5 per cent, less than one-half the increase in the 1960-64 period of widespread price stability.

\section{Professional Workers}

A third category of workers is labeled professional workers. Examining Table $\mathrm{V}$ we see that, unlike the skilled or unskilled categories, or union and white collar categories, the selected groups of professional workers in Table $V$ received substantially larger in

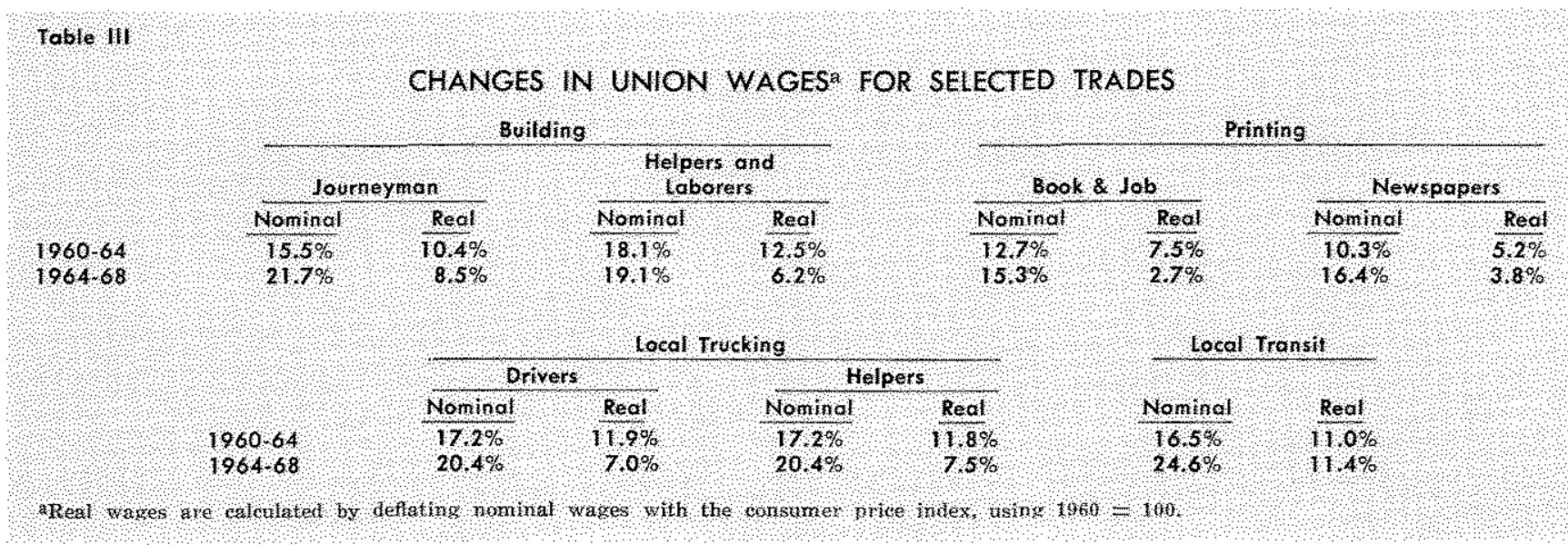


701011

EARNINGS OF WHITE COLLAR WORKERS

$(1961=1001$

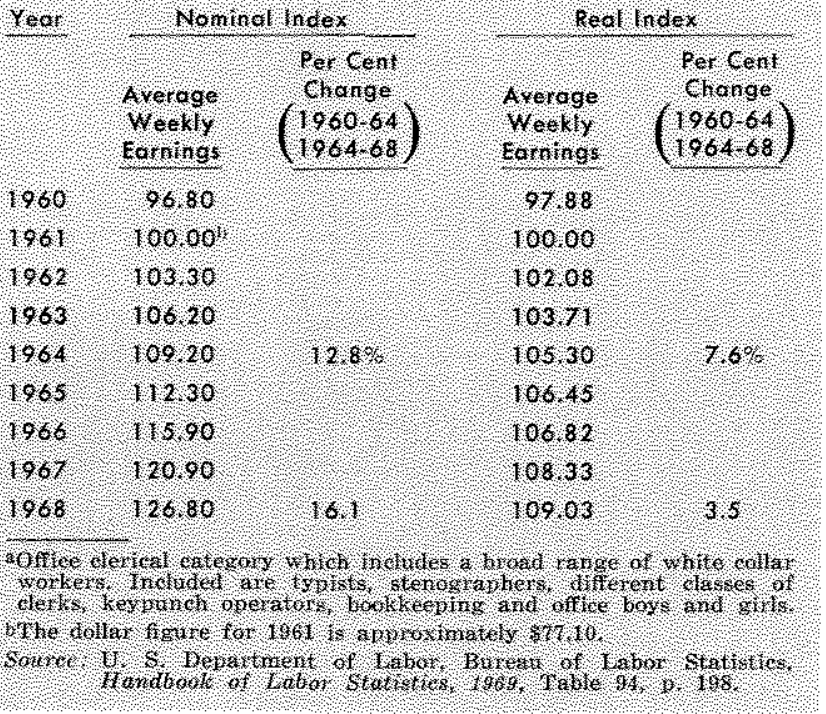

creases in both nominal and real wages in the three year period 1964-67 of rapidly rising prices than in the 1961-64 period of price stability.

Most of these groups made marked gains in real terms in 1968 when prices were rising at their most rapid rate. For example, real wages of engineers rose 5.4 per cent in the three-year period $1964-67$, slightly less than the 5.6 per cent increase in real wages during the previous three years. From 1967 to 1968 average salaries of engineers in nominal terms rose by 7.6 per cent. This sharp rise in nominal terms offset the continued upward movement in prices, and as a result, their real wages showed an increase of 8.9 per cent from 1964-68.

\section{Wealthholders}

An individual has available to him a wide array of real and financial assets in which he can hold his wealth. He may acquire real assets such as land, houses, or other real goods, or he may acquire one of the many different types of financial assets.

\section{Financial Assets}

Financial assets may be divided into two broad classes, money and other financial assets. The basis for distinction used here is that money is the financial asset which yields no nominal return to the holder. Other financial assets yield, or are expected by wealthholders to yield, a nominal or money rate of return.

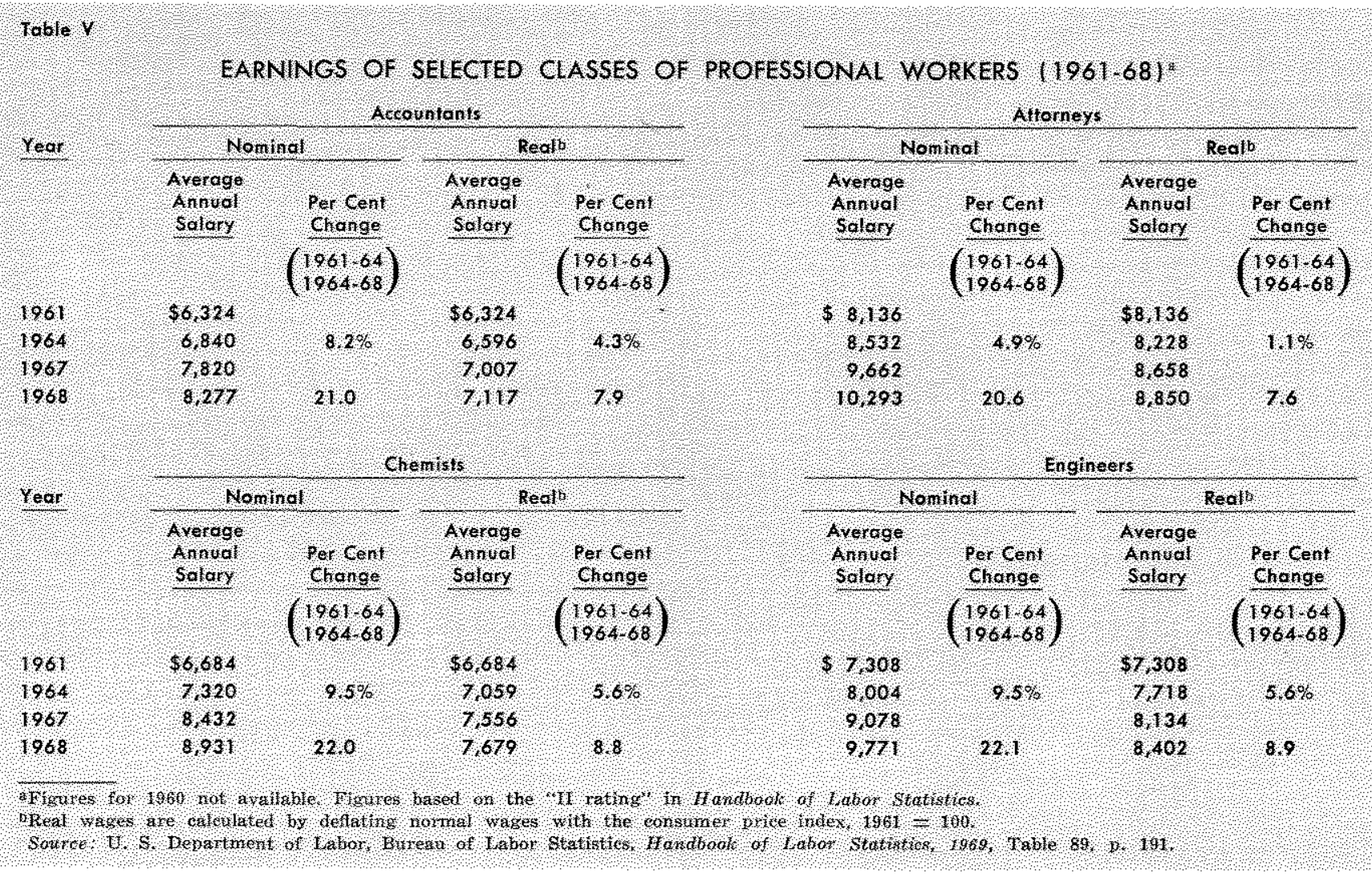


For an analysis of the effects of inflation on the holders of financial assets we shall distinguish effects on the wealthholder's nominal wealth from effects on his real wealth; and the impact of inflation on his flow of returns in nominal and real terms.

For purpose of analysis seven widely held financial assets were selected:

(1) savings and loan shares

(2) mutual savings bank deposits

(3) time deposits at commercial banks

(4) corporate bonds

(5) U. S. Government bonds

(6) municipal bonds

(7) common stock

Several major differences exist between groups of these assets. The first three, savings and loan shares, mutual savings bank deposits, and time deposits at commeroial banks, represent legal claims to fixed amounts of money. In most cases, this claim may be exercised on demand by the holder of the claim or after only a short period of time. The next three items, corporate, U.S. Government, and municipal bonds, represent rights to a fixed amount of money only at maturity, usually much longer into the future. From the time they are issued until maturity, their magnitude of exchange value in terms of money depends upon the valuation which market participants place on the future flow of money payments they offer. Our last financial asset, common stocks, does not represent a claim to any fixed money payment, either currently or in the future.

Fixed Dollar Value Financial Assets - To give some initial comparisons, let us assume that in mid-1960 an individual bought $\$ 1,000$ of one of the fixed dollar value assets. At the end of each period his wealth would still be $\$ 1,000$ in nominal terms. However, the asset holder lost real command over goods and services in both periods. During the first four-

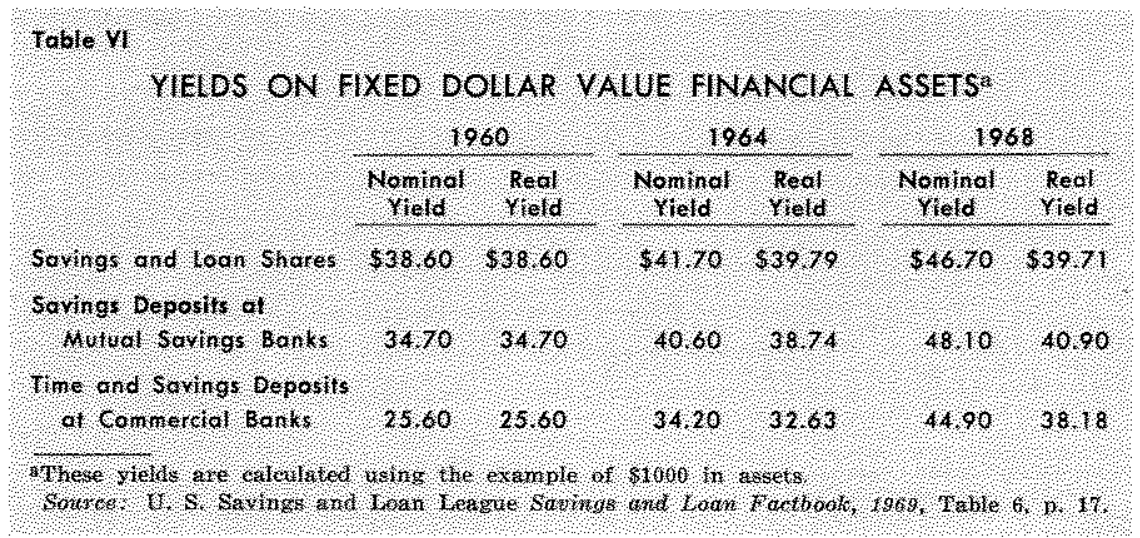

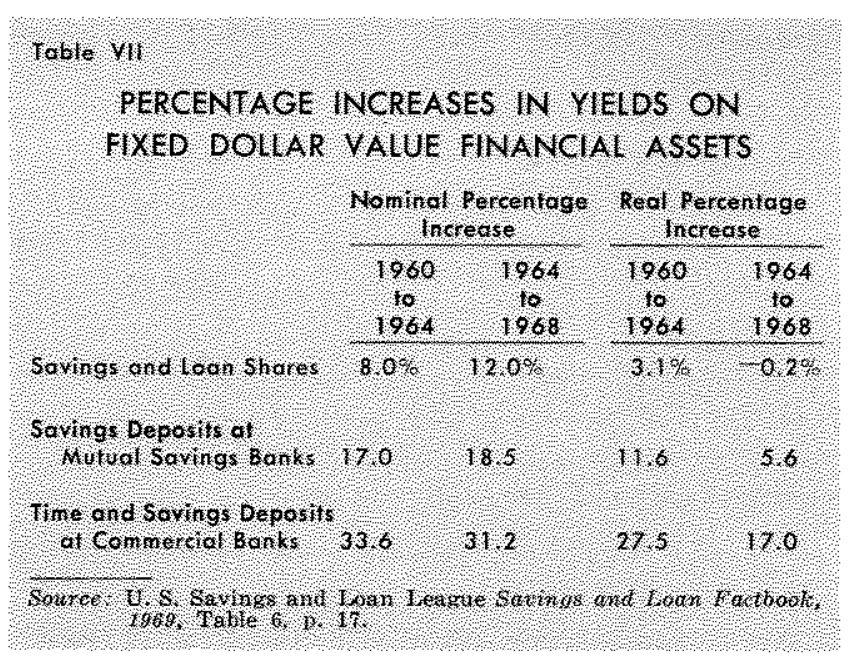

year period the consumer price index rose 4.8 per cent. As a result of the rise in the price level, the command over real goods and services represented by the $\$ 1,000$ in fixed dollar financial assets was reduced to $\$ 954.20$ in 1964. During the second comparison period the holder of this type of asset suffered a much greater real loss. As the price level rose 12 per cent from 1964 through 1968, the asset holder found that his initial $\$ 1,000$ in 1960 dollars repre. sented only about $\$ 850.34$ in real purchasing power in 1968.

From the flow side, holders of this type of asset experienced substantial increases in nominal payments in both periods. In the first comparison period the nominal return on all three fixed dollar value financial assets rose more rapidly than the price level, and hence the real rate of return received by holders of all three of these assets rose. For example, as shown in Table VI, the holder of a $\$ 1,000$ in savings and loan shares received a flow of $\$ 41.70$ in dividends in nominal terms in 1964 compared to $\$ 38.60$ in 1960. As illustrated in Table VII this represented an 8 per cent increase in nominal terms and a 3.1 per cent increase in real terms.

During the second comparison period, although the nominal yields on these assets rose sharply, much of the increase in nominal terms was taken up in price increases. ${ }^{5}$ As Table VII shows, in nominal terms the yields on savings and loan shares rose by an additional 12 per

\footnotetext{
5The much smaller increases in real yields on fixed dollar financial assets in the second period to a significant degree reflects the fact that their maximum nominal yields are fixed by regulatory authorities.
} 
cent, raising nominal yields on $\$ 1,000$ of shares to $\$ 46.70$. However, in real terms the yield on savings and loan shares fell shightly from $\$ 39.79$ in 1964 to $\$ 39.71$ in 1968 .

The nominal yield on time deposits at commercial banks rose more rapidly than the price level from 1964 through 1968, and holders of this financial asset experienced a 17 per cent increase in real yields on these assets. However, these results were much less than the 27.5 per cent increase in real yields holders of debt obligations of commercial banks obtained during the four years of prevailing price stability. ${ }^{6}$

Financial Assets with Money Values Fixed Only at Maturity - In this section we examine how holders of three widely held classes of bonds fared during our two comparison periods. The dollar value of these assets is fixed only at maturity. As the market places different valuations on the flow of money payments offered by these assets, the money exchange value of these assets varies over the life of the bond.

This revaluation of money flows offered by bonds is represented by inverse movements of their prices and yields. As the public places a lower valuation on the stream of payments which the claim represents, the market price of the bond falls and its effective yield rises. The relationship between prices and effective yields can be seen in Table VIII.

The holder of U.S. Govermment bonds over the 1960-64 period would have suffered about a 2 per cent decline in the nominal value of his bonds. Hold ers of corporate bonds would have found in 1964 that the price of these bonds was approximately the same as in 1960 . Holders of municipal bonds would have been able to sell these assets in 1964 at a 7.3 per cent higher price than in 1960 . In real terms, the rise of the consumer price index reduced the real value of any given money claim. Hence, in real terms holders of U.S. Government and corporate bonds were worse off in 1964 than in 1960; only holders of municipal bonds gained in real terms.

BThe above discussion should not lead to a confusion between levels and percentage changes in levels. The person who held $\$ 1000$ of savings and loan shares over the $1960-68$ period wolld have received, on the average, a much larger flow of returns in nominal and real terms than if he hat held a time deposit acootnt at a commercial bank.
In the 1964.68 period of accelerating price inflation, bond holders suffered much larger capital losses in nominal and real terms. From 1964 through 1968 the price of U.S. Government bonds fell 14.4 per cent, municipal prices fell 16.1 per cent, and corporate bond prices declined 19.7 per cent. Not only did bond holders experience a drastic decline in nominal values of their assets, but as the rise in the price index accelerated, they found the exchange value in real goods of their declining nominal values fell about $2^{1 / 2}$ times as rapidly as during the $1960-64$ period of relatively stable prices.

Common Stocks - Of the broad classes of financial assets being considered, only common stocks in creased both the nominal and real wealth of the asset holder in both periods. In the 1964-68 period the Standard and Poor's 500 Stock Index (a broad measure of the magnitude of the money exchange value of common stocks) rose 21.3 per cent. How. ever, this was only 60 per cent as great a percentage increase as the 36 per cent rise in the Stock Index in the $1960-64$ period. $^{7}$

A much larger rise in the consumer price index in the more recent period meant that holders of com mon stocks not only fared worse in the second period in nominal terms, but they also fared considerably worse in real terms. It is interesting to note that in the second period the real wealth of holders of com mon stock rose only 8.1 per cent, compared to 29.8 per cent in the period 1960-64.

\footnotetext{
TThe market prices of common stocks are heavily influenced by the level of business activity. 1960 was a trough in business activity. To remove some of the cyclical influence on our analysis, an average of 1959,1960 , and 1961 was used for 1960 .
}

Page 32

\begin{tabular}{|c|c|c|c|c|c|c|c|}
\hline \multirow[t]{2}{*}{ Year } & \multicolumn{2}{|c|}{ 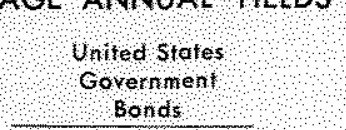 } & \multicolumn{2}{|c|}{$\begin{array}{l}\text { state and Local } \\
\text { Municipal } \\
\text { Bonds }\end{array}$} & \multicolumn{3}{|c|}{$\begin{array}{l}\text { Corpondte } \\
\text { Aad } \\
\text { Bonds }\end{array}$} \\
\hline & $\begin{array}{c}\mathrm{Averoge} \\
\mathrm{reld}\end{array}$ & Pres & $\begin{array}{l}\text { Averose } \\
\text { Yeld }\end{array}$ & Price & & Averoge. & erce \\
\hline 1960 & $401 \%$ & $\$ 86,22$ & $3.69 \%$ & $\$ 103,90$ & & $4.41 \%$ & $\$ 94,60$ \\
\hline 1961 & 9,90 & 87.55 & 3.60 & 10780 & & 4.35 & 95.20 \\
\hline 1982 & 3.95 & 8694 & 3,30 & 11210 & & 433 & 96,20 \\
\hline 1963 & 400 & 86.31 & 3.28 & 11,30 & & 426 & 96,80 \\
\hline 1964 & 415 & 84,46 & 328 & 111,50 & & 4,40 & 95.10 \\
\hline 1965 & 421 & 8376 & 334 & 11060 & & 4,9 & 93,90 \\
\hline 1966 & 4,66 & 78,63 & 390 & 102,60 & & 513 & 86,10 \\
\hline 1967 & 4.85 & 76.55 & 399 & 100.50 & & 551 & 8180 \\
\hline 1968 & 525 & 72,33 & 448 & 9350 & & 818 & 76.40 \\
\hline
\end{tabular}


In the first comparison period the dividend payments received by stockholders rose from $\$ 13.4$ billion to $\$ 17.8$ billion, a 33 per cent increase. In the $1964-68$ period the flow of dividend payments rose to $\$ 24.6$ billion, a 38 per cent increase. In nominal terms, the percentage increases in the flow of payments to stockholders was somewhat greater in the latter period. However, the increased flow of dividends in the latter period represented a somewhat smaller increase in real purchasing power, 23 per cent, compared to 27 per cent in the earlier period.

The assertion that common stocks are a better hedge against inflation than the other types of financial assets we considered is borne out by the evidence. However, although stockholders fared better in inflation relative to holders of the other financial assets we discussed, holders of common stock benefited much more in the earlier period of extensive price stability than in the latter period of rapidly rising prices. It seems difficult to support an assertion that stockholders benefited more in inflation when the percentage increase in their real wealth was much greater under four years of generally stable prices than under four years of rapidly rising prices.

\section{Real Assets}

Sometimes the general assertion is made that inflation destroys the incentive to save by wiping out the real value of wealth accumulated by past aots of saving. This statement fails to take into account that saving may occur by additions to wealth in the form of real assets as well as financial assets. As the magnitude of the exchange value of money in terms of real goods and services falls, holders of real assets benefit from inflation in nominal terms and suffer no loss in real terms. To examine the effects of inflation on holders of real wealth we have selected two real assets, land and houses.

Land - As shown by Table IX, the average market value of an acre of farmland increased in both comparison periods. In the $1964-68$ period of inflation, the average market value of an acre of farmland rose by 29 per cent, compared to an 18.5 per cent increase over the previous four years.

When we adjust both nominal increases for price level changes, the spread between the two periods is reduced. However, in contrast to all the financial assets discussed, the real wealth of landowners showed a somewhat larger percentage increase in the period of rapidly rising prices, 15 per cent, compared to 13 per cent in our comparison period of widespread price stability.

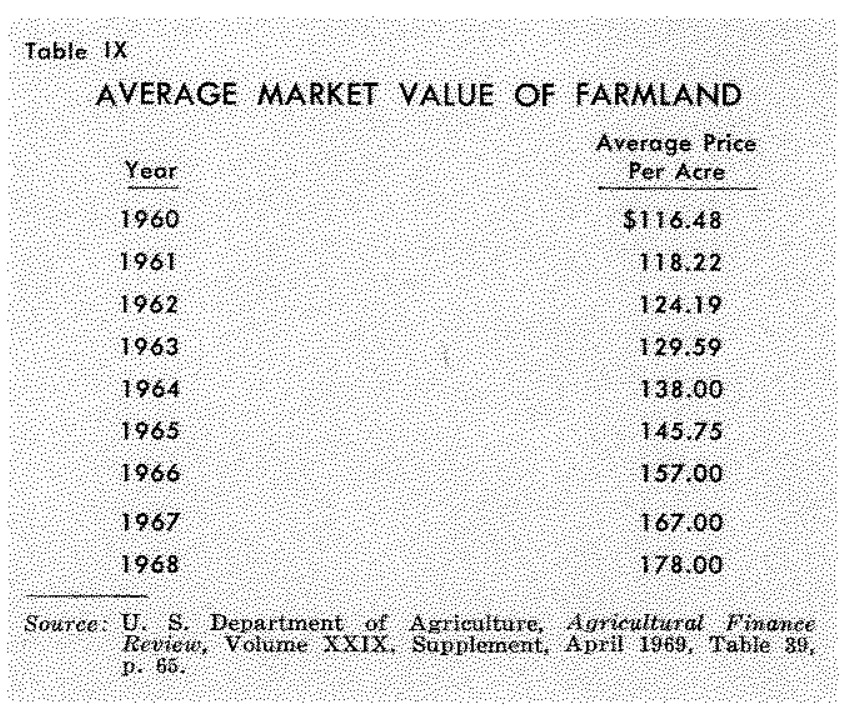

Houses - Over the eight-year period we are considering, the price of houses rose sharply. From $\$ 13,800$ in 1960, the average construction cost of new homes increased to $\$ 15,550$ in 1964 , and then rose to $\$ 18,675$ in 1968. To analyze the effects of inflation on homeowners the net wealth measure is used.

We must take into account at least two other factors in order to use the net wealth measure. The majority of the funds used for the purchase of most homes are borrowed. When a person borrows to purchase a house, he generally agrees to pay a fixed monthly payment to the mortgage lender for a period of years; he agrees to give up a fixed amount of nominal purchasing power each month until the mortgage is paid off. The homeowner decides to forego present and futire command over real output for present and future command over the flow of services from a specific real asset, a house.

The second factor we must consider is that over time a real asset is used up, or depreciates. In general, as a house is used over a period of time, the flow of services it can provide decreases, hence the market value placed on the flow of services offered by the house also declines.

To take into account the two factors, mortgage buying and depreciation, three assumptions are made in the following example:

(1) A house is bought in 1960 on a 25 -year mortgage with 20 per cent of the purchase price as a down payment.

(2) The mortgage is repaid in equal monthly installments over the 25-year period.

(3) The house depreciates at the same rate as the mortgage is paid off. 
Using assumptions (1) through (3) in our example, we have:

Purchase price of a house in $1960=\$ 13,800$

Downpayment $=20$ per cent of $\$ 13,800=\$ 2,760$

Mortgage $=80$ per cent of $\$ 13,800=\$ 11,040$

Yearly mortgage repayments $=$

$$
\$ 11,040 \div 25 \text { years }=\$ 441.60
$$

Yearly depreciation of house

$=\$ 441.60$

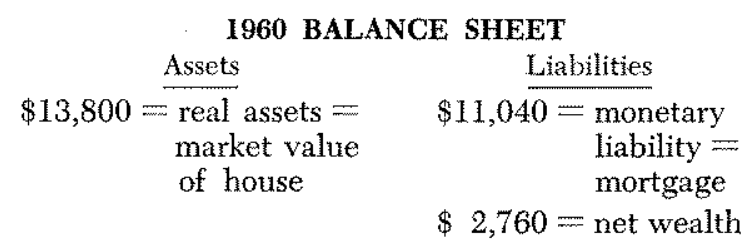

At the end of 1964 the balance sheet has changed. Over the four years 1961 throngh 1964, the homeowner repays $\$ 1,776.40$ of his mortgage ( $4 \times \$ 441.60)$, and his house depreciates by this amount. The market value of his house in 1964 equals the construction cost of a new house $(\$ 15,500)$ less the depreciation of his home $(\$ 1,766.40)$.

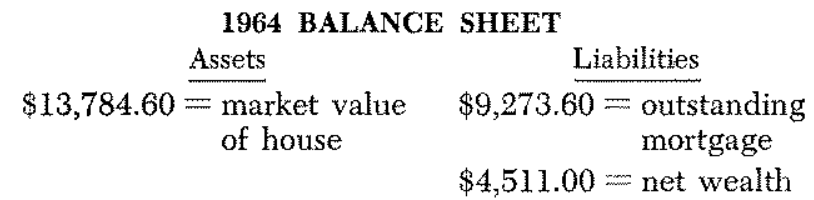

At the end of 1968, the average homeowner has repaid an additional $\$ 1,766.40$ on his mortgage, and his house has depreciated by this amount. The market value of his house in 1968 is $\$ 18,675$ (the construction cost of a new house) minus $\$ 3,532.80$ (eight years of depreciation).

$$
\begin{aligned}
& 1968 \text { BALANCE SHEET }
\end{aligned}
$$

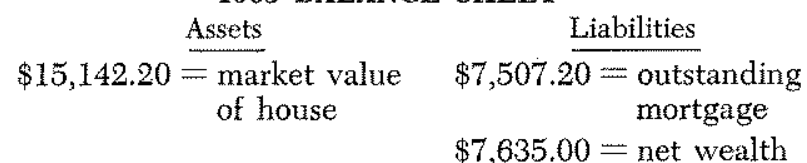

Examining the balance sheets we see that over each comparison period the homeowner experienced a substantial rise in nominal net wealth. In the first period nominal net wealth rose by 63.4 per cent, and in the second period by 69.3 per cent.

Table $\mathrm{X}$ illustrates the contribution of factors acting to change the net wealth position of the homeowner. The use of the house over time decreases the market value of its flow of services and hence operates to decrease the net wealth of the homeowner (decreases the dollar value of his real asset). The repayment of the mortgage decreases the homeowner's monetary liabilities and hence operates to in- crease his net wealth. Assuming no change in the general price of houses there would be no change in his net wealth.

However, due to the marked increase in the general construction cost of houses over each period, the market value of the real asset held by the homeowner increased. In the 1960-64 period the rise in the construction cost of houses resulted in an increase of $\$ 1,751$ in the homeowners nominal net wealth. At the end of the first four-year period, the homeowner in our example could have sold his house for approximately what he paid for the house in 1960. In 1968 , because the construction cost of houses advanced more rapidly in the 1964-68 period than over the previous four years, he could have sold his house at a price almost 10 per cent above what he paid in 1960 .

When we adjust the changes in nominal net wealth for changes in prices over our two periods, we also record substantial gains for the homeowner. In real terms, the homeowner's net wealth rose by $\$ 1,544$ in the fouryear period 1960-64 and then showed an even greater increase in the 1964-68 period, increas. ing by $\$ 2,188$.

Again to clarify the meaning of the term "benefited," we mean that the homeowner's real command over goods and services increased. For example, between 1960 and 1964 his real net wealth was augmented by $\$ 1,544$. If he had sold his house at its market value of $\$ 13,784,60$ in 1964 and repaid his outstanding mortgage, his command over real goods and services would have been $\$ 1,544$ greater than if he sold his house and repaid his mortgage in 1960 . Over the more recent four-year period, the homeowner in our example benefited even more in the sense that his real command over goods and services rose by $\$ 2,188$.

For the potential home buyer, the purchase price of a house is only one consideration. Another major consideration is the cost of borrowing funds to make

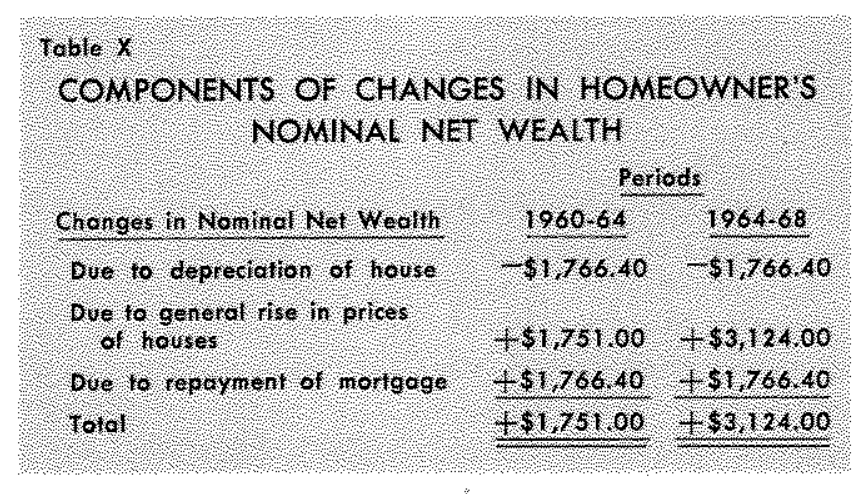


the purchase, During the first of our comparison periods the contract rate on conventional first mortgages remained farly stable at around 5.75 to 5.85 per cent. On balance, it would not have cost our average individual more in nominal terms to obtain funds to finance the purchase of a home in 1964 than earlier in the first period.

The second period shows quite a different picture. Over this period the cost of financing a home in creased along with other market interest rates. Whereas the average cost of financing a new home by a conventional first mortgage was 5.78 per cent in 1964 , this rate rose to an average of 6.83 per cent for 1968 and was at 7.08 per cent in the second half of 1968. On balance, if instead of buying a home in 1964, an individual had delayed buying a home until the second half of 1968 , not only would the average construction cost of the home have been about 20 per cent higher, but the financing costs would have risen by 22.5 per cent.

In real terms, if a person had financed a home on a conventional first mortgage during the period 1961 through 1965, he would have gained in real terms during the following three years. However, after 1965 the current cost of mortgage financing rose faster than the consumer price index. If a person delayed buying a house in 1965, when mortgage rates were about 5.74 per cent, until 1966 when mortgage rates rose to an average of 6.14 per cent, he would not have experienced a reduction of his real financing costs to the 1965 level until late 1968.

Suppose our average individual became an average homeowner in 1960. Using our example, we assume he purchased a $\$ 13,800$ house in 1960 with a 20 per cent downpayment and the balance financed over 25 years with a financing cost of 5.75 per cent. On this basis, his monthly payments would be $\$ 69.48$. Our individual has decided to give up $\$ 69.48$ a month in nominal command over goods and services in exchange for the How of services from a house.

By 1964 the homeowner would still be giving up $\$ 69.48$ a month in nominal purchasing power. However, since the consumer price index rose by 4.8 per cent over these four years, he would be giving up slightly less in real purchasing power each month, about $\$ 66.30$ in real purchasing power.

In contrast, the average homeowner found that, in the four-year period since 1964, the real purchasing power he was giving up each month decreased about $2^{1 / 2}$ times as rapidly as over the previous fout years of general price stability. In our illustration the real purchasing power of $\$ 69.48$ in 1960 dollars fell to $\$ 59.08$ in 1968 .

\section{Retired Persons}

One of the common maxims in most discussions of the effects of inflation is that people on fixed incomes, especially retired persons, "lose" during periods of inflation. Since inflation is a situation where the magnitude of the exchange value of money in terms of real assets declines, individuals whose flow of money payments remains fixed find their income commands a smaller flow of real goods and services in an inflationary situation. The truth of the assertion that retired persons lose during inflation depends upon the assumption that their income payments remain "fixed" and that net nominal increases in the value of their other assets do not offset their loss of real incone.

One form of income flow to retired persons is social security benefits. As illustrated by Table XI the average amount of monthly benefits received by retired persons did not stay fixed over the 1960 through 1968 period.

Reflecting several increases in social security benefits, average monthly payments to retired workers rose from $\$ 74.04$ in 1960 to $\$ 98.86$ in 1968 . In the second half of the period, when prices began to rise rapidly, benefits rose by 27.4 per cent compared to an increase of only 4.8 per cent over the 1960 through 1964 period. Considering the rise in the consumer price index over each period, the purchasing power in real terms of Government transfer payments to retired persons

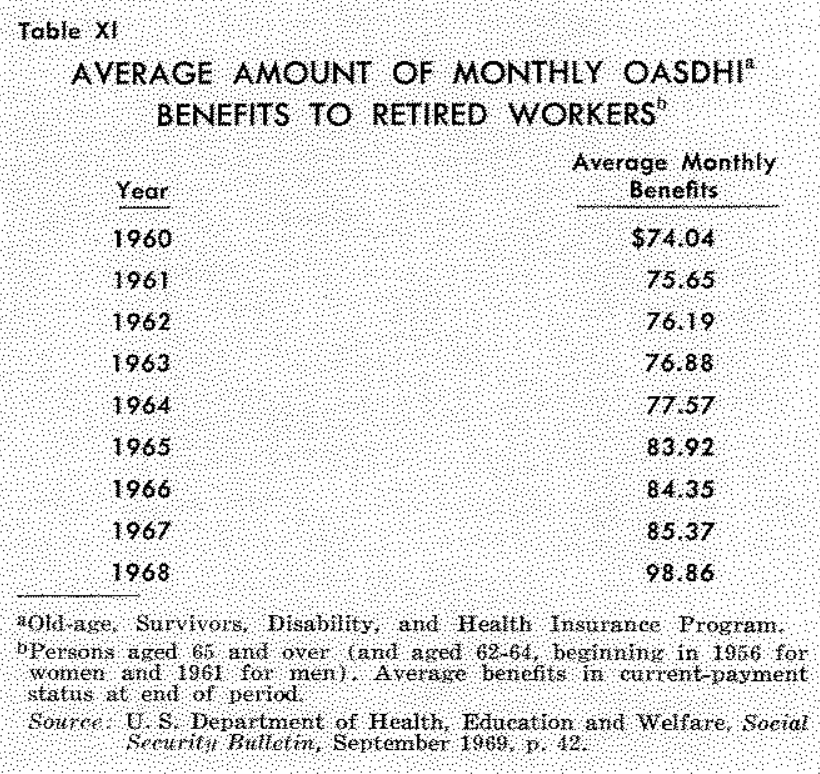


was about the same in 1964 as in 1960, then increased by approximately 13.6 per cent from 1964 through 1968.

For many retired persons, social security payments comprise only a portion of the income they depend upon after retirement. A portion of their income derives from returns from financial assets they have purchased over a period of years. Such assets include the value of life insurance, savings and loan shares, bank deposits, bonds and common stock. In the section on the effects of inflation on holders of financial assets, we saw that holders of these assets did not fare as well in the recent $1964-68$ period of rapid price inflation as in the $1960-64$ period of much more stable prices.

To the extent that retired persons held real assets, they were made no worse off by inflation and, depending on the asset, may have benefited. Many people, when they reach retirement age, have paid off the mortgage on their home. As the price of homes has risen, the magnitude of the exchange value of this asset in terms of other real assets has increased. Alternatively, since they are no longer net debtors with regard to their house, they do not benefit as much from inflation as those individuals who are still net debtors on their homes.

On balance, rapidly rising social security benefits offset part of the effects of inflation on retired persons. However, unless they were solely dependent upon such payments for retirement income, it does not appear that retired persons made any real gains in the period from 1964 through 1968. In fact, compared to the previous four years of price stability, in many cases retired persons may have suffered a decline in their ability to command real output.

${ }^{8}$ The change in real purchasing power for retired persons may have been less than indicated by deflating by the consumer price index. The prices of many services, which might be expected to weigh more heavily in retired person's budgets, such as medical care, physicians fees, property taxes, and public transportation, increased over 20 per cent during this period compared to a 12 per cent rise in the total index.

\section{Conclusions}

We have concluded that, of all the classes of workers considered, only certain groups of professional workers, such as accountants, attomeys, engineers, and chemists, could be said to have benefited more with respect to incone flows in the 1964"68 period of inflation than in the previous period of general price stability. The broad classes of skilled workers, unskilled workers, union workers, and white collar workers that were examined all benefited less in the 1964-68 period than during the 1960-64 period.

Individuals, on the average, in their separate roles as asset holders, benefited more in the $1964-68$ period than in the 1960-64 period only in their roles as owners of real assets - land and houses. With respeot to all financial assets considered except common stocks, individual asset holders lost during the latter period. Holders of common stocks, although they did not lose in the $1964-68$ period, benefited substantially less than during the 1960-64 comparison period.

Finally, to the extent that retired persons are solely dependent upon social security benefits, the sharp upward revisions of these transfer payments resulted in a rise in retired persons' real command over goods and services. However, to the extent that retired persons also depended upon insurance payments, fixed dollar value securities, and bonds, they lost real purchasing power in the 1964-68 period.

Any particular individual can only determine in which of our comparison periods he fared better by examining his total balance sheets for both comparison periods. This article has attempted to give a general framework in which the individual can complete this analysis. Rather than making broad assertions about the nebulous "evils of inflation," a definition of benefit and loss has been presented for the reader. If the individual is alerted to the dangers of confusing nominal benefits with real benefits, he has a means of judging the effects of the recent inflation on his own ability to command real ontput. 